\title{
PSYCHOACTIVE SUBSTANCES AND SEXUALLY TRANSMITTED INFECTIONS AMONG MILITARY POLICE OFFICERS FROM CENTRAL- WESTERN, BRAZIL
}

\author{
SUBSTÂNCIAS PSICOATIVAS E INFECÇÕES SEXUALMENTE TRANSMISSÍVEIS \\ EM SERVIDORES DA FORÇA POLICIAL DO CENTRO-OESTE, BRASIL
}

\author{
José Rodrigues de Melo NETO ${ }^{1}$; Carlos Henrique Sousa GUERRA ${ }^{2}$;

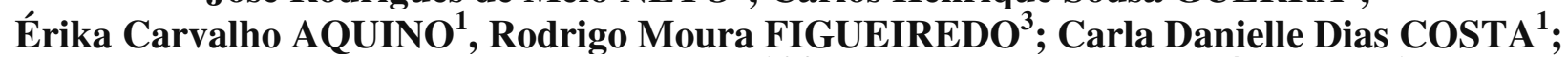 \\ Sérgio Henrique Nascente $\operatorname{COSTA}^{\mathbf{1 , 2 , 3}}$; Keila Correia de ALCÂNTARA $^{1}$ \\ 1. Universidade Federal de Goiás; 2. Pontifícia Universidade Católica de Goiás; 3. Hospital da Polícia Militar do Estado \\ de Goiás.
}

\begin{abstract}
The aim of this work was to evaluate the profile of military police officers regarding the use of psychoactive substances and the presence of Sexually Transmitted Infections (STI). Cross-sectional study carried out with military police officers in 2015 in the central-western, Brazil. The ASSIST (Alcohol, Smoking and Substance Involvement Screening Test) questionnaire was applied to investigate the use of psychoactive substances and serology was performed for syphilis, viral B and C hepatitis and HIV. Cronbach's alpha and Pearson Correlation Coefficient were employed. The ASSIST presented alpha coefficients of Cronbach almost perfect for tobacco $(\alpha=0.83)$ and substantial for the use of alcohol $(\alpha=0.70)$. Of 657 police officers, $78.5 \%$ consumed psychoactive substances at some point in their lives, with $76.7 \%$ alcohol, $28.5 \%$ tobacco, and 5.2\% illegal psychoactive substances. A short intervention was required for $23.3 \%$ of police officers who used psychoactive substances, and $1.4 \%$ should be referred for treatment. Tobacco use was strongly associated with the use of more than one psychoactive substances in life $(\varphi=0.9327)$, and the use of marijuana showed a moderate correlation with cocaine/crack $(\varphi=0.5241)$. The prevalence of STI was $14.0 \%$, being $7.6 \%$ for $\mathrm{HBV}, 6.8 \%$ syphilis, $0.5 \% \mathrm{HIV}$, and $0.3 \% \mathrm{HCV}$. HBV/syphilis and HBV/HIV co-infection were observed in $1.1 \%$ and $0.1 \%$, respectively. There was no correlation between STI and use of psychoactive substances. The prevalence of HBV and syphilis was higher among police officers than in the general population. The ASSIST questionnaire was consistent when applied to this group and can be a significant tool for monitoring and decision making for timely intervention.
\end{abstract}

KEYWORDS: Drugs. Alcoholism. Tobacco. Sexually Transmitted Infections. Military Police.

\section{INTRODUCTION}

Military police are subject to imminently stressful situations and long working hours without appropriate rest. In addition, the high demand for work together with a reduced number of professionals often leads to adverse physiological, psychological, and legal consequences (MANSUR et al., 2001) that may promote or increase use of psychoactive substances (OIT, 2003; JUNIOR, 2016).

Monitoring of alcohol, tobacco, and other psychoactive substance use is essential in promoting health among Brazilians, given that abusive psychoactive substance use is a significant public health issue (SPEAR et al., 2009; SILVA et al., 2016). In order to identify and characterize the use of psychoactive substances by the population, reliable and feasible screening instruments are remarkably necessary (HENRIQUE et al., 2004;
SILVA et al., 2016). From this perspective, the Alcohol, Smoking, and Substance Involvement Screening Test (ASSIST) recommended by the World Health Organization (WHO) was first applied in 2004 in Brazil and is currently used as a primary health care screening of the population (HENRIQUE et al., 2004).

Furthermore, several studies have shown that the use of psychoactive substances increases the chance of infection by the virus that causes Sexually Transmitted Infections (STI), such as human immunodeficiency virus (HIV), hepatitis C virus (HCV), and hepatitis B virus (HBV) (NOVAIS et al., 2009; GUIMARÃES et al., 2015; GUIMARÃES et al., 2016). The euphoric and relaxing effect of psychoactive substances provides attitudes that would not normally be taken in the absence of them, like eventual and unprotected sexual intercourse. The presence of STI among police officers is equal to or greater than the rates associated with the non- 
Psychoactive substances...

military population (SINGER et al., 2010; BROWN et al., 2011; SPAULDING et al., 2012; ARMED FORCES HEALTH SURVEILLANCE CENTER, 2013; HARBERTSON et al., 2013).Although these conditions are widely discussed in society, Brazilian studies that analyzed psychoactive substances abuse and its consequences on police officers are still scarce (COSTA et al., 2010) . The loss of highly trained, professional military officers to STI and psychoactive substances have a major impact on the corporation and on security and trained officers are difficult and expensive to replace (COSTA et al., 2010). In this way, identifying and establishing strategies to fill potential gaps and contribute to improving the quality of life of military police is essential for both these professionals and the society. This study aimed to determine the prevalence of the use of psychoactive substances and STI, as well as to verify the correlation between one and another among military police officers.

\section{MATERIAL AND METHODS}

We conducted a cross-sectional study with military police officers assisted in 2015 by the Center for Comprehensive Health of the Military Police (CSIPM) in the metropolitan region and countryside of the state of Goiás, central-western Brazil. All Police officers who were awaiting care by the Comprehensive Health Center of the Military Police (CSIPM) were invited to participate in the study. Who was in favor of participating in the study, signed a Free and Informed Consent Term agreeing to participate in all stages of the research (Ethics committee CAAE: 23551514.9.0000.5083).

The ASSIST was employed to estimate a score that determines the need for an brief intervention, its duration, and if the participant should be referred for treatment based on the use of psychoactive substances in their lifetime or the trimester before to the analysis. It was applied through a face-to-face interview. Sociodemographic data such as age, place of work and working time in the corporation were provided by the employee registration department.Psychoactive substances that were used without a prescription and for the sole purpose of leisure were considered as psychoactive substance abuse. The main result variable was the score obtained from the answers to the ASSIST test for each of the screened psychoactive substances. ASSIST is a brief questionnaire used to identify risky drug use developed by the WHO and adapted and validated in Brazil (HENRIQUE et al., 2004). The questionnaire consists of 8 questions on recent and
NETO, J. R. M. et al

lifelong consumption of 9 substances (tobacco, alcohol, marijuana, cocaine, amphetamines or other stimulants, sleeping pills, hallucinogenic drugs, inhalants, and others). Only, tobacco and alcohol are considered legal in Brazil. Several domains of the questions are considered (time of use, recent use, desire to consume, health issues, social issues, legal issues, difficulty to stop consuming, etc). According to the WHO, from 0 to 3 points means no intervention is recommended as the risk of a condition related to the substance is low; from 4 to 26 points (11-26 for alcohol), brief intervention is recommended; and for scores of 27 points and above, intensive treatment is recommended. The analysis then classifies the risks into 3 levels (low, moderate, and serious).

After ASSIST interview, $10 \mathrm{~mL}$ of blood were collected, but not everyone agreed to participate in this stage of the research. Serum was frozen at $-20^{\circ} \mathrm{C}$ in the BIOTEC laboratory of the Faculty of Pharmacy of UFG, where anti-HIV 1/2 immunoenzymatic tests were performed (AlereBiolisa ${ }^{\circledR}$, Brazil). Positive samples were confirmed by Immunoblot (InnoGenetics® Belgium). We also employed the total anti-HBc (Interkit ${ }^{\circledR}$, Brazil), HBsAg (Interkit ${ }^{\circledR}$, Brazil), antiHBsAg (Interkit ${ }^{\circledR}$ Brazil), anti-HCV (Interkit ${ }^{\circledR}$ Brazil), and anti-Treponema pallidum (Dia.Pro Diagnostics ${ }^{\circledR}$ Italy) tests. Vaccination coverage for hepatitis B was not investigated, but individuals who were exclusively positive for anti-HBs were considered immunized.Data processing and statistical analysis were carried out with Stata 13.0 software (StataCorp. 2013. Stata Statistical Software: Release 13. College Station, TX, US: StataCorp LP). During the analysis, the sociodemographic characteristics of the studied population were analyzed employing the frequency distribution, mean age, and their standard deviation, assuming the $95 \%$ confidence interval (95\% CI). To validate the reliability of the internal consistency of the ASSIST questionnaire, Cronbach's alpha test was calculated and interpreted as proposed by Leontitsis and Pagge (2007) and Landis and Koch (1977). Cronbach's alpha test was calculated only for alcohol and tobacco considering that the number of users of other types of psychoactive substances in this population was small.

To determine the association between the investigated variables we applied the Pearson correlation test $(\varphi)$. For visualization, we generated a Correlation Matrix using the $\varphi$ values. To interpret the correlation coefficients, we applied the categorization method proposed by CallegariJacques (2003). 


\section{RESULTS}

A total of 758 military officers were invited to participate in the survey. Of these, $96.8 \%$ (734/758) answered the ASSIST questionnaire, $89.7 \%(680 / 758)$ performed the serologies for IST, and $86.7 \%(657 / 758)$ performed both ASSIST questionnaire and IST serology. Therefore, only those who participated in both stages $(n=657)$ were included in the study. The median age of the participants was 43 years ( 21 to 65 years, $s d=7.5$ ), $93.9 \%(617 / 657)$ were male, $63.0 \%$ (414/657) were married, 61\% (405/657) lived/worked in the metropolitan region, and 26.2\% (172/657) had a history of STI. Regarding the use of psychoactive substances, $78.5 \%$ (516/657) [95\% CI: 75.2-81.5\%] of the servers used psychoactive substances at some point in their lives. The rates of alcohol and tobacco use corresponded to $76.7 \%(504 / 657)$ and $28.5 \%$ (187/657), respectively, while the use of other types of psychoactive substances considered illicit was reported by $5.2 \%(34 / 657)$ of the police officers. Among those who reported using illicit substance, $73.5 \%$ (25/34) used marijuana, and 26.5\% (9/34) used cocaine/crack. The sociodemographic characteristics of the military police are shown in Table 1. We observed that the reliability analysis of the applied questionnaire presented values of the standard Cronbach alpha coefficients almost perfect for tobacco $(\alpha=0.83)$ and substantial for alcohol use $(\alpha=0.70)$.

Of the police officers reporting use of psychoactive substances, $23.3 \%$ (120/516) needed brief intervention, and $1.4 \%$ (7/516) should be referred for treatment, with $97.6 \%$ (124/127) using alcohol and 59.1\% (75/127) using tobacco derivatives. Of these, the majority of the individuals were 44 years old or older and had longer working periods in the corporation (Table 1). Police officers who used some illicit substance and needed some intervention were younger than those who did not use illicite psychoactive substances but required some intervention and had less working time $<01$. Of the $6.6 \%(34 / 516)$ who used illicit substances, $50.0 \%(17 / 34)$ needed brief intervention, compared to $21.4 \%(103 / 482)$ of those who used licit substances $(p=0.16)$. Table 2 presents the intervention criteria according to the ASSIST questionnaire

The prevalence of STI among military police officers was $14.0 \%(92 / 657)$ [95\% CI: 11.6-
NETO, J. R. M. et al

$16.9 \%$ ]. We observed that HBV infection was present in 7.6\% (50/657), syphilis in 6,8\% (45/657), HIV in $0.5 \%$ (3/657), and HCV in $0.3 \%(2 / 657)$ of the individuals. The HBV/syphilis and HBV/HIV coinfection were found in $1.1 \%(7 / 657)$ and $0.1 \%$ (1/657) of individuals, respectively. In addition, we found that $38.9 \%(236 / 657)$ of the participants were considered immunized, as they presented positive serology for anti-HBs (Table 3).

Among the police officers with STI $(\mathrm{n}=$ 92), $65.2 \%$ (60/92) were married, $65.2 \%$ (60/92) had more than 25 years of working time, $64.1 \%$ (59/92) lived in the metropolitan region, and $60.9 \%$ (56/92) were over 44 years old (Table 1). The number of syphilis and HBV cases was higher among individuals over 44 years of age to syphilis( $\mathrm{p}=0,008)$ and to HBV $(\mathrm{p}=0,03)$ and HIV seropositivity occurred primarily among men who declared themselves to be single, lived in the metropolitan area, and had no history of STI. Positive serology for STI was found in $27.2 \%$ (25/92) of the police officers who used psychoactive substances and needed brief intervention or treatment, and $72.8 \%$ (67/92) of police officers who did not require intervention.

The use of tobacco had a strong correlation with use of more than one psychoactive substances in life $(\varphi=0.9327)$, and the use of marijuana showed a moderate correlation with cocaine/crack use $(\varphi=0.5241)$ (Figure 1). No correlation was observed between STI and the use of licit or illicit substances and the need of intervention. 


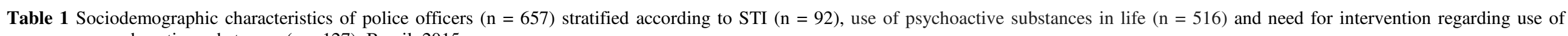
psychoactive substances $(\mathrm{n}=127)$, Brazil, 2015.

\begin{tabular}{|c|c|c|c|c|c|c|c|c|c|c|c|c|}
\hline \multirow[b]{2}{*}{ CHARACTERISTICS } & \multicolumn{3}{|c|}{$\begin{array}{l}\text { TOTAL } \\
(n=657)\end{array}$} & \multicolumn{3}{|c|}{$\begin{array}{l}\text { Police officers with Sexually } \\
\text { Transmitted Infections } \\
(\mathbf{n = 9 2 )}\end{array}$} & \multicolumn{3}{|c|}{$\begin{array}{l}\text { Police officers who used psychoactive } \\
\text { substances in life } \\
(\mathbf{n}=\mathbf{5 1 6})\end{array}$} & \multicolumn{3}{|c|}{$\begin{array}{l}\text { Police officers in need of } \\
\text { intervention/treatment regarding use } \\
\text { of psychoactive substances } \\
(\mathrm{n}=127)\end{array}$} \\
\hline & $\mathbf{n}$ & $\%$ & CI* \% & $\mathbf{n}$ & $\%$ & $\mathrm{CI} * \%$ & $\mathbf{n}$ & $\%$ & $\mathrm{CI} * \%$ & $\mathbf{n}$ & $\%$ & $\mathrm{CI} * \%$ \\
\hline \multicolumn{13}{|l|}{ SEX } \\
\hline Male & 617 & 93.9 & $91.8-95.5$ & 91 & 98.9 & $94.1-100.0$ & 490 & 95.0 & $92.7-96.5$ & 123 & 96.9 & $92.1-99.1$ \\
\hline Female & 40 & 6.1 & $4.5-8.2$ & 1 & 1.1 & $0.0-5.9$ & 26 & 5.0 & $3.5-7.3$ & 4 & 3.1 & $0.9-7.9$ \\
\hline \multicolumn{13}{|l|}{ Age (years) } \\
\hline$<44$ & 339 & 51.6 & $47.8-55.4$ & 36 & 39.1 & $29.1-49.9$ & 266 & 51.6 & $47.2-55.8$ & 60 & 47.2 & $38.3-56.3$ \\
\hline$\geq 44$ & 318 & 48.4 & $44.6-52.2$ & 56 & 60.9 & $50.1-70.9$ & 250 & 48.4 & $44.2-52.8$ & 67 & 52.8 & $43.7-61.7$ \\
\hline \multicolumn{13}{|l|}{ MARITAL STATUS } \\
\hline Married & 414 & 63.0 & $59.3-66.6$ & 60 & 65.2 & $54.6-74.8$ & 322 & 62.4 & $52.1-66.5$ & 84 & 66.1 & $57.2-74.3$ \\
\hline Not married & 243 & 37.0 & $33.4-40.7$ & 32 & 34.8 & $25.2-45.4$ & 194 & 37.6 & $33.5-41.8$ & 43 & 33.9 & $25.7-42.8$ \\
\hline \multicolumn{13}{|l|}{ REGION } \\
\hline Metropolitan & 405 & 61.6 & $57.9-65.3$ & 59 & 64.1 & $53.5-73.9$ & 325 & 63.0 & $58.7-67.0$ & 77 & 60.6 & $51.6-69.2$ \\
\hline Countryside & 252 & 38.4 & $34.7-42.1$ & 33 & 35.9 & $26.1-46.5$ & 191 & 37.0 & $33.0-41.3$ & 50 & 39.4 & $30.8-48.4$ \\
\hline \multicolumn{13}{|c|}{ YEAR OF ENTERING } \\
\hline \multicolumn{13}{|c|}{ THE CORPORATION } \\
\hline Until 1992 & 328 & 50.0 & $46.1-53.7$ & 60 & 65.2 & $54.6-74.8$ & 256 & 49.6 & $45.3-53.9$ & 67 & 52.8 & $43.7-61.7$ \\
\hline 1993 onwards & 311 & 47.3 & $43.6-51.2$ & 29 & 31.5 & $22.2-42.0$ & 247 & 47.9 & $43.6-52.2$ & 53 & 41.7 & $33.1-50.8$ \\
\hline NA & 18 & 2.7 & $1.7-4.3$ & 3 & 3.3 & $0.7-9.2$ & 13 & 2.5 & $1.5-4.3$ & 7 & 5.5 & $2.2-11.0$ \\
\hline \multicolumn{13}{|l|}{ USE OF } \\
\hline \multicolumn{13}{|l|}{ PSYCHOACTIVE } \\
\hline \multicolumn{13}{|l|}{ SUBSTANCES IN LIFE } \\
\hline \multicolumn{13}{|l|}{ Licit } \\
\hline Alcohol & 62 & 9.4 & $7.4-11.9$ & 16 & 17.4 & $10.3-26.7$ & - & - & - & 62 & 48.8 & $39.8-57.8$ \\
\hline Tobacco & 46 & 7.0 & $5.3-9.2$ & 6 & 6.5 & $2.4-13.7$ & - & - & - & 46 & 36.2 & $27.9-45.2$ \\
\hline Alcohol and tobacco & 14 & 2.1 & $1.3-3.5$ & 1 & 1.1 & $0.0-5.9$ & - & - & - & 14 & 11.0 & $6.2-17.8$ \\
\hline \multicolumn{13}{|l|}{ Illicit } \\
\hline Only one & 1 & 0.1 & $0.0-0.9$ & 0 & - & - & - & - & - & 1 & 0.8 & $0.0-4.3$ \\
\hline More than one & 2 & 0.3 & $0.1-1.1$ & 1 & 1.1 & $0.0-5.9$ & - & - & - & 2 & 1.6 & $0.2-5.6$ \\
\hline Licit and illicit & 2 & 0.3 & $0.1-1.1$ & 1 & 1.1 & $0.0-5.9$ & - & - & - & 2 & 1.6 & $0.2-5.6$ \\
\hline \multicolumn{13}{|l|}{ SEXUALLY } \\
\hline \multicolumn{13}{|l|}{ TRANSMITTED } \\
\hline \multicolumn{13}{|l|}{ INFECTIONS } \\
\hline No & 565 & 86.0 & $83.1-88.4$ & - & - & - & 442 & 85.7 & $82.4-88.4$ & 102 & 80,3 & $72,3-86,8$ \\
\hline Yes & 92 & 14.0 & $11.6-16.9$ & - & - & - & 74 & 14.3 & $11.6-17.6$ & 25 & 19.7 & $13.2-27.7$ \\
\hline
\end{tabular}


Table 2 Intervention criteria, according to the ASSIST questionnaire, in police officers, Brazil, 2015 ( $\mathrm{n}=127$ )

\begin{tabular}{|c|c|c|c|c|c|c|c|c|}
\hline \multirow[b]{2}{*}{ SUBSTANCES } & \multicolumn{2}{|c|}{$\begin{array}{l}\text { Used } \\
\text { psychoactive } \\
\text { substance in the } \\
\text { last } 3 \text { months }\end{array}$} & \multicolumn{2}{|c|}{$\begin{array}{l}\text { Suggested } \\
\text { Brief } \\
\text { Intervention }\end{array}$} & \multicolumn{2}{|c|}{$\begin{array}{l}\text { They should be } \\
\text { referred for } \\
\text { treatment }\end{array}$} & \multicolumn{2}{|c|}{$\begin{array}{l}\text { TOTAL FOR } \\
\text { BRIEF } \\
\text { INTERVENTION } \\
\text { OR TREATMENT }\end{array}$} \\
\hline & n & $\%$ & $\mathbf{n}$ & $\%$ & $\mathrm{n}$ & $\%$ & $\mathbf{N}$ & $\%$ \\
\hline \multicolumn{9}{|l|}{ LICIT } \\
\hline Alcohol & 64 & 50.4 & 60 & 47.2 & 2 & 1.6 & $62^{\#}$ & 48.8 \\
\hline Tobacco & 7 & 5.5 & 41 & 32.3 & 5 & 3.9 & $46^{\#}$ & 36.2 \\
\hline Alcohol and tobacco & 46 & 36.2 & 15 & & - & - & $15^{\#}$ & \\
\hline \multicolumn{9}{|l|}{ ILLICIT } \\
\hline Hallucinogens and opioids & 0 & - & 1 & 0.8 & - & - & $1^{*}$ & 0.8 \\
\hline Sedatives/Sleeping Pills & 0 & - & 1 & 0.8 & - & - & $1^{*}$ & 0.8 \\
\hline $\begin{array}{l}\text { Marijuana, cocaine/crack, } \\
\text { amphetamine, sedatives/ } \\
\text { sleeping pills, inhalants and } \\
\text { opioids }\end{array}$ & 0 & - & 1 & 0.8 & - & - & $1^{*}$ & 0.8 \\
\hline \multicolumn{9}{|l|}{ LICIT AND ILLICIT } \\
\hline Tobacco and marijuana & 0 & - & 1 & 0.8 & - & - & 1 & 0.8 \\
\hline Alcohol and sedatives & 1 & 0.8 & - & - & - & - & NA & NA \\
\hline $\begin{array}{l}\text { Alcohol, cocaine/crack, } \\
\text { amphetamine and } \\
\text { hallucinogens }\end{array}$ & 1 & 0.8 & - & - & - & - & NA & NA \\
\hline $\begin{array}{l}\text { Alcohol, tobacco, } \\
\text { marijuana, } \\
\text { cocaine/crack } \\
\text { and inhalants }\end{array}$ & 1 & 0.8 & 1 & 0.8 & - & - & 1 & 0.8 \\
\hline TOTAL & 120 & 94.5 & 120 & 94.5 & 7 & 5.5 & 127 & 100.0 \\
\hline
\end{tabular}

NA: Not available. ${ }^{*}$ younger and had ${ }^{\#}$ less working time than who did not use illicite psychoactive substances; Fisher test $(\mathrm{p}<0.05)$.

Table 3 Sexually transmitted infections in police officers, Brazil, $2015(\mathrm{n}=657)$

\begin{tabular}{llll}
\hline SEXUALLY TRANSMITTED INFECTIONS & $\mathbf{n}$ & $\mathbf{\%}$ & CI* (95\%) \\
\hline Hepatitis B $^{\#}$ & 50 & 7.6 & $5.8-9.9$ \\
HBsAg & 0 & - & - \\
Anti-HBc alone & 6 & 0.9 & - \\
Anti-HBc + Anti-HBsAg & 44 & 6.7 & - \\
Syphilis ${ }^{\#}$ & 45 & 6.8 & $5.2-9.0$ \\
HIV & 3 & 0.5 & $0.2-1.3$ \\
Hepatitis C & 2 & 0.3 & $0.1-1.1$ \\
\hline
\end{tabular}

There were eight cases of coinfection being 1.1\% (7/657) for HBV and syphilis and 0.1\% (1/657) for HBV and HIV. Anti-HBsAg was found in $38.9 \%(236 / 657)$ [CI: $35.1 \%$ to $42.8 \%$ ]; *CI: Confidence Interval $95 \% ;{ }^{*}$ higher among individuals over 44 years of age to syphilis $(\mathrm{p}=0,008)$ and to $\mathrm{HBV}(\mathrm{p}=0,032))$; Fisher test. 


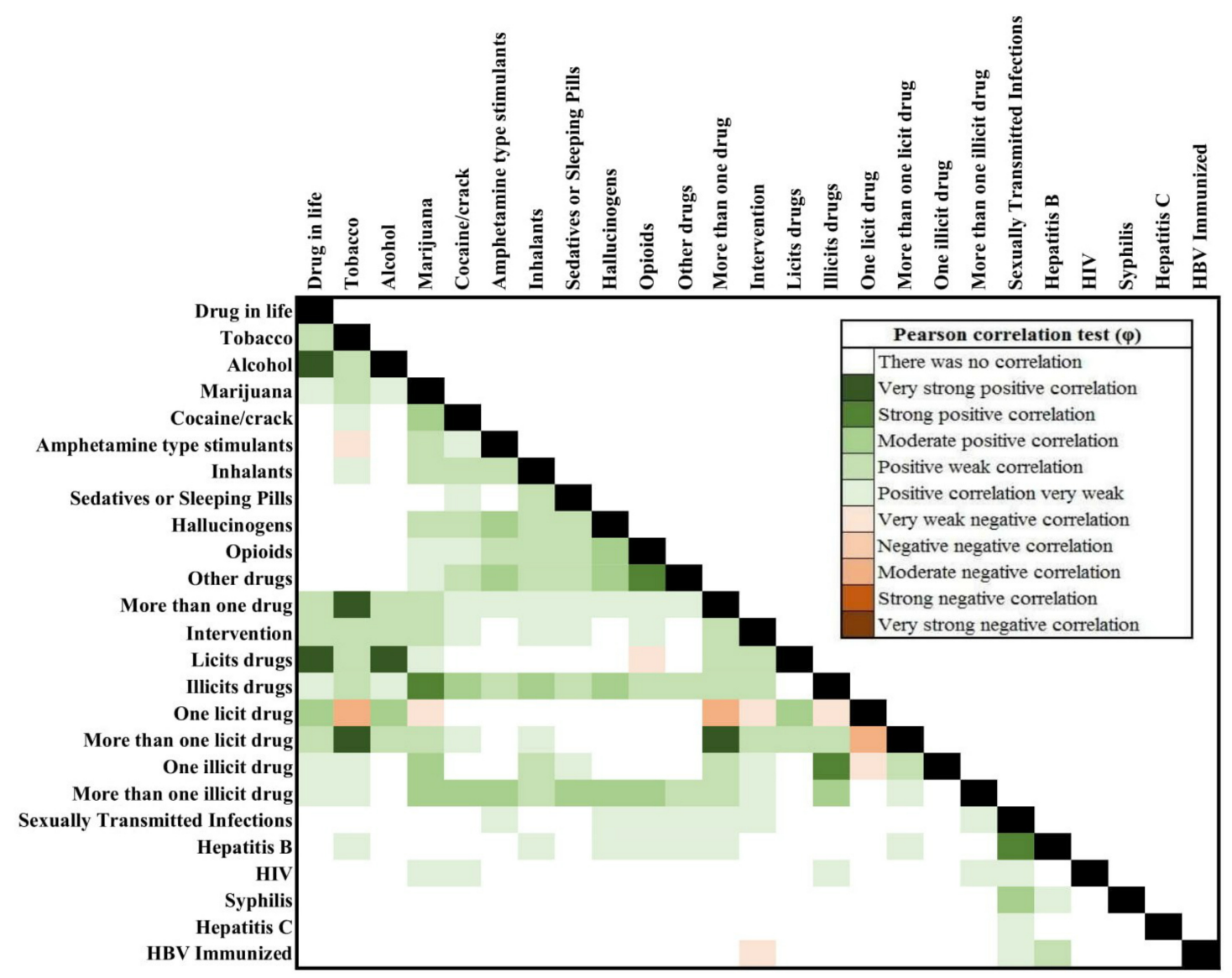

Figure 1. Matrix of correlation between some investigated variables, police officers, Brazil, 2015

\section{DISCUSSION}

The vast majority of the military police officers reported the use of alcohol and tobacco and some of them needed intervention or treatment, primarily as a result of the use of these licit substances. So, the use of licit substances can not be neglected inside the corporation. By applying the ASSIST, we identified the risk groups that may require intervention measures, we found that approximately $50 \%$ of the servers that used illicit psychoactive substances needed a brief intervention, which reinforces the necessity of a periodic investigation and more detailed analysis on the use of psychoactive substances in this population. The intervention can be an effective means of raising awareness and helping the police to stop abusing psychoactive substances, since this behavior may interfere with their performance in work, social, and family life (COSTA et al., 2010). In Chile, the ASSIST was implemented in primary care and reinforced the need to identify risk groups (POBLETE et al., 2017).

The use of illicit psychoactive substances found in this study, although lower than those observed in the military police in the region and the overall population aging 15-64 years (COSTA et al., 2010; BRASIL, 2011), is observed within the corporations and should be managed to improve the quality of life and work of military police officers. The use of psychoactive substances is investigated in the military police of Goiás state when the officers enter the corporation. The initial screening is performed with hair samples. Further, when the psychoactive substances use is suspected during police career, urine samples are collected for examination. ASSIST should be used to survey the use of psychoactive substances of abuse. Although indirectly investigated, it may be of fundamental importance, mainly because ASSIST also allows by directing the police to a possible intervention or treatment. An example of this was a study in Thailand that implemented ASSIST in primary care and presented promising and satisfying results (ASSANANGKORNCHAI et al., 2014).

Studies show that there is a relationship between the use of psychoactive substances of abuse and the presence of STI (PINHEIRO et al., 2011; GUIMARÃES et al., 2014; ANDRADE et al., 2016). However, in this study, we did not observe 
Psychoactive substances...

any correlation between STI and psychoactive substances use. But, we found a higher prevalence of STI among police officers who used any psychoactive substances and needed intervention or treatment. The prevalence of $0.3 \%$ of $\mathrm{HCV}$ among military police was similar to that found in blood donors, pregnant women, children that live in the street, and sex workers of the same region ranging from $0.2-3.0 \%$ (FRANÇA, 2011; MARINHO, 2013). HIV infection was identified in $0.5 \%$ of the police and is concordant with the estimated by UNAIDS in 2014 for people aged 15-49 in Brazil, which was $0.4-0.7 \%$ (UNAIDS, 2017). We found that $7.6 \%$ of the police officers presented hepatitis $\mathrm{B}$, which is similar to the rates observed in Brazilian federal highway police officers (SILVA, 2016) and US public security professionals, which ranges between 8-6\% (AVERHOFF et al., 2002). In contrast, our observations are higher when compared to the prevalence of hepatitis $\mathrm{B}$ in the general population of the Midwest Brazil (4.3\%) (PEREIRA et al., 2010). For syphilis, we found a higher prevalence when compared to the rate found in the general population of the Brazilian centralwest region between 2010 and 2017 (5.3\%) (BRASIL, 2017). Thus, we suggest that this professional group is more vulnerable to $\mathrm{HBV}$ and syphilis than the general population, and measures of control and prevention of these two infections should be employed in the military force police.

HBV can be prevented through vaccination, however, we found that less than $40 \%$ of the police were immunized against hepatitis B. Although this rate is compatible with the vaccination coverage in the municipality of Goiânia $335.78 \%$ and $24.25 \%$ for individuals ageing 25-29 and 30-34, respectively (SI-PNI, 2013), an increased immunization rate was expected, as police officers, firefighters, military personnel, professionals, and health students have legal support for vaccine coverage, regardless of age group since 1991 (BRASIL, 2013). Another fact that may contribute to the reduced percentage of immunization is the lack of administration of the three doses of the HBV vaccine.
NETO, J. R. M. et al

The ASSIST questionnaire may be selfapplicable or applied by an interviewer. When selfapplicable, it may not be entirely understood and imply incorrect or incomplete answers (SILVA et al., 2016). In contrast, when applied by an interviewer, it may inhibit the interviewee from telling the truth (SILVA et al., 2016). The percentage of individuals who reported using illicit psychoactive substances in this study may have been underestimated since the ASSIST was completed by an interviewer, which may have caused fear of being punished or dismissed by the police officer despite the guarantee of confidentiality of the study. But the answers of ASSIST were highly reliable and presented acceptable and almost perfect values for alcohol and tobacco, respectively.

Finally, a research specifically focused on military officers allows the diagnosis of the current situation and points out the need to create and / or implement specific policies for drug and STI prevention, since military police activity requires good health, concentration and balance to make the right decisions, in the various situations of public security.

\section{CONCLUSIONS}

Older policemen with extended working hours had higher rates of STI and psychoactive substance use. Moreover, we observed that tobacco use is related to the use of more than one psychoactive substance, as well as the use of marijuana is moderately associated with the use of cocaine/crack.

We did not observe a correlation between STI and the use of psychoactive substances and need for intervention, but when considering the increasing rates of STI and psychoactive substances in the general population, the appliance of preventive strategies in addition to the use of screening instruments may improve the quality of life of police offices, given their importance for maintaining public safety.

RESUMO:O objetivo deste trabalho foi avaliar o perfil dos policiais militares quanto ao uso de substâncias psicoativas e a presença de Infecções Sexualmente Transmissíveis (IST). Estudo transversal realizado com policiais militares em 2015 no centro-oeste do Brasil. O questionário ASSIST (Alcohol, Smoking and Substance Involvement Screening Test) foi aplicado para investigar o uso de substâncias psicoativas e foi realizada sorologia para sífilis, Hepatites virais, B e C ,e HIV. O alfa de Cronbach e o coeficiente de correlação de Pearson foram empregados. O ASSIST apresentou coeficientes alfa de Cronbach quase perfeitos para o tabaco $(\alpha=0,83)$ e substancial para o uso de álcool $(\alpha=0,70)$. Dos 657 policiais, 78,5\% usaram alguma substância psicoativa em algum momento da vida, sendo 76,7\% álcool, 28,5\% tabaco e 5,2\% substâncias 
ilícitas. Uma intervenção breve foi necessária para 23,3\% dos policiais que usavam substâncias psicoativas, e $1,4 \%$ deveriam ser encaminhados para tratamento. $\mathrm{O}$ uso de tabaco foi fortemente associado ao uso de mais de uma substância psicoativa na vida $(\varphi=0,9327)$, e o uso de maconha mostrou uma correlação moderada com a cocaína/crack ( $\varphi=0,5241)$. A prevalência de IST foi de $14,0 \%$, sendo 7,6\% para HBV, $6,8 \%$ sífilis, $0,5 \%$ HIV e $0,3 \%$ HCV. A coinfecção HBV/sífilis e HBV/HIV foi observada em 1,1\% e 0,1\%, respectivamente. Não houve correlação entre IST e uso de substâncias psicoativas. A prevalência de HBV e sífilis foi maior entre policiais do que na população geral. O questionário ASSIST mostrou-se consistente quando aplicado a este grupo e pode ser uma ferramenta importante para monitoramento e tomada de decisão para intervenção oportuna. Policiais.

PALAVRAS-CHAVE: Drogas. Alcoolismo. Tabaco. Infecções Sexualmente Transmissíveis.

\section{REFERENCES}

ANDRADE, R. F. V.; ARAÚJO, M. A. L.; DOURADO, M. I. C.; MIRANDA, A. B. E.; REIS, C. B. S. Prevalência e fatores associados à violência entre parceiros íntimos após a revelação do diagnóstico de doenças sexualmente transmissíveis ao parceiro. Cadernos de Saúde Pública, Rio de Janeiro, v. 32, n. 7, e00008715, 2016 . http://dx.doi.org/10.1590/0102-311X00008715.

ARMED FORCES HEALTH SURVEILLANCE CENTER. Sexually transmitted infections, active component, US Armed Forces, 2000-2012. MSMR, v. 20, n. 2, p. 5, 2013.

ASSANANGKORNCHAI, S.; BALTHIP, Q.; EDWARDS, J. G.; WITH THE ASSISTANCE OF THE ASSIST-SBI DEVELOPMENT CO-INVESTIGATORS. Implementing the Alcohol, Smoking, Substance Involvement Screening Test and linked brief intervention service in primary care in Thailand. Journal of Public Health, v. 36, n. 3, p. 443-449, 2014. https://doi.org/10.1093/pubmed/fdu011

AVERHOFF, F. M.; MOYER, L. A.; WOODRUFF, B. A.; DELADISMA, A. M.; NUNNERY. J.; ALTER, M. J.; MARGOLIS, H. S. Occupational exposures and risk of hepatitis B virus infection among public safety workers. Journal of occupational and environmental medicine, v. 44, n. 6, p. 591-596, 2002.

BRASIL. Ministério da Saúde. Secretaria de Vigilância em Saúde. Nota Técnica Conjunta n. ${ }^{\circ}$ 02/2013/CGPNI/DEVEP e CGDHRV/DST-AIDS/SVSE/MS; 2013. Available in:

http://www.aids.gov.br/sites/default/files/anexos/page/2010/43122/notatecnicaconjuta02_ampliacaohepbate49a nos_ms_25_13875.pdf Accessed in: 01 Jun. 2017

BRASIL. Ministério da Saúde. Secretaria de Vigilância em Saúde. Departamento de DST, Aids e Hepatites Virais. Pesquisa de Conhecimentos, Atitudes e Práticas na População Brasileira de 15 a 64 anos 2008. Brasília (DF): Ministério da Saúde, Secretaria de Vigilância em Saúde, Departamento de DST, Aids e Hepatites Virais, 2011. Available in:

http://bvsms.saude.gov.br/bvs/publicacoes/pesquisa_conhecimentos_atitudes_praticas_populacao_brasileira.pdf Accessed in : 10 may 2017

BRASIL. Ministério da Saúde. Secretaria de Vigilância em Saúde. Boletim epidemiológico Sífilis, v. 48, n. 36, 2017. [citado em 2018 Fev 12]. http://www.aids.gov.br/pt-br/pub/2017/boletim-epidemiologico-de-sifilis-2017.

BROWN, A. E.; ROSS, D. A.; SIMPSON, A. J.; ERSKINE, R. S.; MURPHY, G.; PARRY, J. V.; GILL, O. N. Prevalence of markers for HIV, hepatitis B and hepatitis C infection in UK military recruits. Epidemiology \& Infection, v. 139, n. 8, p. 1166-1171, 2011.

CALLEGARI-JACQUES, S. M. Bioestatística: princípios e aplicações. Artmed Editora, 2009. 
COSTA, S. H.; CUNHA, L. C.; YONAMINE, M.; PUCCI, L. L.; OLIVEIRA, F. G.; SOUZA, C. G.; MESQUITA, G. A.; VIEIRA, A. P; VINHAL, L. B.; DALASTRA, J.; LELES, C. R. Survey on the use of psychotropic drugs by twelve military police units in the municipalities of Goiânia and Aparecida de Goiânia, state of Goiás, Brazil. Revista Brasileira de Psiquiatria, v. 32, n. 4, p. 389-395, 2010. https://dx.doi.org/10.1590/S1516-44462010005000023

FRANÇA, D. D. S. Infecção pelo vírus da hepatite C em mulheres profissionais do sexo em Goiânia, Goiás. Dissertação (Mestrado em Enfermagem) - Programa de Pós-Graduação em Enfermagem, Faculdade de Enfermagem, Universidade Federal de Goiás, Goiânia, 2011.

GUIMARÃES, L. A.; MAYER, V. M.; BUENO, H. P.; MINARI, M. R.; MARTINS, L. F. Síndrome de bournout e qualidade de vida de policiais militares e civis. Revista Sul Americana de Psicologia, v. 2, n. 1, p. 98-122, 2014.

GUIMARÃES, R. A.; SILVA, L. N.; FRANÇA, D. D. S.; DEL-RIOS, N. H. A.; CARNEIRO, M. A. S.; TELES, A. S. Comportamentos de risco para doenças sexualmente transmissíveis em usuários de crack. Revista Latino-Americana de Enfermagem, v. 23, n. 4, p. 628-634, 2015.

GUIMARÃES, R. A.; RODOVALHO, A. G.; FERNANDES, I. L.; SILVA, G. C.; FELIPE, R. L.; VERA, I.; GREGÓRIO, V. D.; LUCCHESE, R. Transactional sex among noninjecting illicit drug users: implications for HIV transmission. The Scientific World Journal, v. 2016, p. 1-7, 2016.

HARBERTSON, J.; GRILLO, M.; ZIMULINDA, E.; MUREGO, C.; BRODINE, S.; MAY, S.; SEBAGABO, M.; ARANETA, M. R.; CRONAN, T.; SHAFFER, R. HIV seroprevalence, associated risk behavior, and alcohol use among male Rwanda defense forces military personnel. AIDS and Behavior, v. 17, n. 5, p. 17341745, 2013. https://doi.org/10.1007/s10461-012-0343-6

HENRIQUE, I. F.; MICHELI, D.; LACERDA, R. B.; LACERDA, L. A.; FORMIGONI, M. L. Validação da versão brasileira do teste de triagem do envolvimento com álcool, cigarro e outras substâncias (ASSIST).

Revista da Associação Médica Brasileira, v. 50, n. 2, p. 199-206, 2004.

JUNIOR, I. J. F.; SCHLINDWEIN, V. L.; CALHEIROS, P. R. V. A relação entre o uso de drogas e o trabalho: uma revisão de literatura PSI. Estudos e Pesquisas em Psicologia, v. 16, n. 1, p. 104-122, 2016.

LANDIS, J. R.; KOCH, G. G. The measurement of observer agreement for categorical data. Biometrics, v. 33, n. 1, p. 159-174, 1977.

LEONTITSIS, A.; PAGGE, J. A simulation approach on Cronbach's alpha statistical significance. Mathematics and Computers in Simulation, v. 73, n. 5, p. 336-340, 2007.

MANSUR, A. P.; LOPES, A. I. A.; FAVARATO, D.; AVAKIAN, S. D.; CÉSAR, L. A. M.; RAMIRES, J. A. F. Tendência da mortalidade por doenças circulatórias no Brasil de 1979 a 1996. Arquivos Brasileiros de Cardiologia, v.76, p. $497-503,2001$.

NOVAIS, A. C.; LOPES, C. L.; REIS, N. R.; SILVA, A. M.; MARTINS, R. M.; SOUTO, F. J. Prevalence of hepatitis $\mathrm{C}$ virus infection and associated factors among male illicit drug users in Cuiabá, Mato Grosso, Brazil. Memórias do Instituto Oswaldo Cruz, v. 104, n. 6, p. 892-896, 2009.

OIT. Organização Internacional do Trabalho. Problemas ligados ao álcool e a drogas no local de trabalho: a evolução para prevenção. Genebra; 2003. Available in :

http://www.ilo.org/public/portugue/region/eurpro/lisbon/pdf/pub_problemas.pdf Accessed in 17 Jan. 2018

PEREIRA, L. M. B.; XIMENES, R. A. A.; MOREIRA, R. C. Estudo de prevalência de base populacional das infecções pelos vírus das hepatites A, B e C nas Capitais do Brasil. Universidade Federal de Pernambuco, 2010. 
PINHEIRO, F. K. B.; VINHOLES, D. B.; SCHUELTER-TREVISOL, F. Risco de doenças sexualmente transmissíveis entre policiais militares. Jornal Brasileiro de Doenças Sexualmente Transmissíveis, v. 23, n. 3, p. 134-137, 2011.

POBLETE, F.; BARTICEVIC, N. A.; ZUZULICH, M. S.; PORTILLA, R.; CASTILLO-CARNIGLIA, A. ; SAPAG, J. C. ; VILLARROEL, L.; SENA, B. F. ; GALARCE, M. A randomized controlled trial of a brief intervention for alcohol and drugs linked to the Alcohol, Smoking and Substance Involvement Screening Test (ASSIST) in primary health care in Chile. Addiction, v. 112, n. 8, p. 1462-1469, 2017.

SILVA, D. S. Infecção pelo vírus da hepatite B imunidade vacinal em policiais rodoviários federais de Campo Grande, MS. Dissertação (Mestrado em Enfermagem) - Universidade Federal do Mato Grosso do Sul, Campo Grande, 2016.

SILVA, A. C.; LUCCHESE, R.; VARGAS, L. S.; BENÍCIO, P. R.; VERA, I. Aplicação do instrumento Alcohol, Smoking and Substance Involvement Screening Test (ASSIST): uma revisão integrativa. Revista Gaúcha Enfermagem, v. 37, n.1, e52918, 2016.

SINGER, D. E.; BAUTISTA, C. T.; O'CONNELL, R. J.; SANDERS-BUELL, E.; AGAN, B. K.; KIJAK, G. H.; HAKRE, S.; SANCHEZ, J. L.; SATEREN, W. B.; MCCUTCHAN, F. E.; MICHAEL, N. L.; SCOTT, P. T. HIV infection among US Army and Air Force military personnel: sociodemographic and genotyping analysis. AIDS research and human retroviruses, v. 26, n. 8, p. 889-894, 2010.

SI-PNI. Sistema de Informação do Programa Nacional de Imunizações. Coordenação Geral do Programa Nacional de Imunizações. Secretaria de Vigilância em Saúde. Coberturas vacinais para hepatite B, em uma série histórica de terceiras doses aplicadas e acumuladas de vacinas de mesmo componente por faixa etária de 1 a 49 anos de idade em Goiânia e no Brasil. Sistema de Informação do Programa Nacional de Imunizações. Banco de dados do Ministério da Saúde de 31 de dezembro de 2013. Brasília: Ministério da Saúde, 2013.

SPAULDING, A. B.; LIFSON, A. R.; IVERSON, E. R.; GANESAN, A.; LANDRUM, M. L.; WEINTROB, A. C.; AGAN, B. K.; BAVARO, M. F.; O'CONNELL, R. J.; MACALINO, G. E. Gonorrhoea or chlamydia in a U.S. military HIV-positive cohort. Sexually Transmitted Infections, v. 88, n.4, p. 266-271, 2012. http://dx.doi.org/10.1136/sextrans-2011-050173

SPEAR, S.; TILLMAN, S.; MOSS, C.; GONG-GUY, E.; RANSOM, L.; RAWSON, R. A. Another way of talking about substance abuse: substance abuse screening and brief intervention in a mental health clinic. Journal of Human Behavior in the Social Environment, v. 19, n. 8, p. 959-977, 2009.

UNAIDS. Estatísticas; 2017. Avalable in: http://unaids.org.br/estatisticas/. Accessed in : 20 Jun. 2017 